\title{
On population dynamics in multi-species cultures of diatoms and dinoflagellates
}

\author{
M. ELBRÄCHTER \\ Botanisches Institut der Rbeinisch-Westfälischen Technischen Hocbschule Aachen; \\ Aachen, Federal Republic of Germany
}

\begin{abstract}
In order to assess the phenomena possibly underlying population dynamics and species succession in the sea, the following phytoplankton culture experiments were made. In uni-algal and in multi-algal batch cultures, generation times and cell yields gained during logarithmic growth were determined for the diatoms Biddulphia regia and Coscinodiscus concinnus, as well as for the dinoflagellates Ceratium horridum and Prorocentrum micans. In multi-species cultures, none of the tested organisms showed any influence on generation time, compared with uni-algal cultures. In contrast, the cell yield of different species showed considerable changes depending on the species concerned and the species-combination used. The dinoflagellates $C$. horridum reached, if cultivated together with $B$. regia or $B$. regia and C. concinnus, only $10 \%$ of the cell number of uni-algal cultures. In the combinations tested, $B$. regia produced always more than half of the cell number attained in uni-algal cultures. In multi-species cultures, C. concinnus cell production was not affected. Addition of nitrate and phosphate to stationary-phase multi-species cultures induced further growth. Thus it is concluded that growth is limited by nutrient competition in the multi-species experiments conducted. Possible mechanisms of nutrient competition are discussed.
\end{abstract}

\section{INTRODUCTION}

Many efforts have been made to explain the phenomena of phytoplankton succession and population dynamics, either by analysing field data or by studying the autecology of single species in culture experiments. Field data are very important in studying the functioning of ecosystems, but as many components vary simultaneously and very often independently in natural environments, the reason for changes in natural populations are recognizable only in a very few cases. Numerous culture experiments of single phytoplankton species have been conducted in order to obtain data suitable for explaining plankton growth in the natural habitat. In these experiments, algal responses to variations of such parameters as light, temperature or nutrient concentrations were tested. However, in nature, phytoplankton species usually grow together with other species. It is likely that the species interact in one way or the other and, so far, only very few experiments have proved the question of interaction and competition among coexisting species in multi-species cultures.

In order to assess the phenomena responsible for population dynamics and species 
succession in the sea, the following aspects were investigated in multi-species culture experiments: (1) The possible effect on generation time due to the interaction between two or more species cultivated together; (2) the possible effects of interaction between two or more species cultivated together on cell production. During all experiments, cell densities corresponded to those prevailing in the natural environment.

\section{MATERIAL AND METHODS}

The diatoms Biddulphia regia (Schulze) Ostenfeld, isolated from the plankton near Helgoland, and Coscinodiscus concinnus W. Smith, isolated off Niewport (Belgium), as well as the dinoflagellates Ceratium horridum (Cleve) Gran and Prorocentrum micans Ehrenberg, both isolated near Helgoland, were cultivated in batch cultures employing glass Petri dishes of $5 \mathrm{~cm}$ diameter, filled with exactly $10 \mathrm{ml}$ medium. The medium was prepared after Stosch \& Drebes (1964), but modified by adding only $1 / 10$ of the nutrients nitrogen and phosphorus (Table 1$)$. The sea water $(31.6 \% 0 \mathrm{~S})$ employed was taken off Helgoland in January, 1973. The temperature was kept at $18^{\circ} \mathrm{C} \pm 0.2^{\circ} \mathrm{C}$, illumination at 3300 lux was supplied by "Philips W33" fluorescent tubes with a light/dark cycle of 14:10 hours. To allow physiological adaptation to

Table 1

Modified 'Stosch \& Drebes medium' used in the experiments

\begin{tabular}{|c|c|c|c|}
\hline Seawater & 1.0001 & \multicolumn{2}{|c|}{$31.6 \% \mathrm{~S}$} \\
\hline $\mathrm{NaNO}_{3}$ & $4.25 \mathrm{mg}$ & & $\mu \mathrm{mol}$ \\
\hline $\mathrm{Na}_{2} \mathrm{HPO}_{4} \times 12 \mathrm{H}_{2} \mathrm{O}$ & $1.075 \mathrm{mg}$ & 3 & $\mu \mathrm{mol}$ \\
\hline $\mathrm{FeSO}_{4} \times 7 \mathrm{H}_{2} \mathrm{O}$ & $278 \quad \mu \mathrm{g}$ & 1 & $\mu \mathrm{mol}$ \\
\hline $\mathrm{MnCl}_{2} \times 4 \mathrm{H}_{2} \mathrm{O}$ & $19.8 \mu \mathrm{g}$ & 0.1 & $\mu \mathrm{mol}$ \\
\hline $\mathrm{SiO}_{2}$ & $12 \mathrm{mg}$ & 200 & $\mu \mathrm{mol}$ \\
\hline $\mathrm{Na}_{2} \mathrm{EDTA} \times 2 \mathrm{H}_{2} \mathrm{O}$ & $3.72 \mathrm{mg}$ & 10 & $\mu \mathrm{mol}$ \\
\hline Cobalamin & $0.7 \mu \mathrm{g}$ & 0.00 & $\mu \mathrm{mol}$ \\
\hline After sterile filtration & {$[7.5$} & & \\
\hline
\end{tabular}

culture conditions the species were cultivated under these conditions for at least two months corresponding at least to 5 transfers before starting the experiments. Two controls and at least 3 parallel tests were run in one series of experiments and each series was duplicated at least once.

Each day, the whole population in each Petri dish was counted under the dissecting microscope. Generation times with confidence limits were calculated during the logarithmic growth period. After terminating the experiments, total cell number for each species was counted in the fixed samples. Two different sets of experiments were conducted:

(1) The diatoms Biddulpbia regia and Coscinodiscus concinnus and the dinoflagellate Ceratium horridum were inoculated in Petri dishes either singly or in all combinations possible. From each species 4 individuals were inoculated in each Petri 
dish, and the generation time and the production of cells in the $10 \mathrm{ml}$ medium was followed. After all species had reached the stationary growth phase, $0.1 \mathrm{ml}$ nitrate solution, corresponding to an enrichment of $500 \mu \mathrm{g}$-at $\mathrm{NO}_{3}-\mathrm{N} \mathrm{1}^{-1}$, and $0.1 \mathrm{ml}$ phosphate solution, corresponding to an enrichment of $30 \mu \mathrm{g}$-at $\mathrm{PO}_{4}-\mathrm{P}^{-1}$ were added in order to test whether nutrient competition was responsible for grow th limitation.

(2) In a second set of experiments it was tested whether the dinoflagellate Prorocentrum micans will continue to grow in multi-species cultures after the other species have reached the stationary growth period. In these experiments, 10 individuals of Prorocentrum micans were inoculated; the other procedures were identical to those described above. In addition, it was tested whether $P$. micans will grow if inoculated into stationary-phase cultures of the other algae. In these experiments, $P$. micans was inoculated with 5,10 or 50 individuals. By addition of $0.1 \mathrm{ml}$ nitrate solution, corresponding to an enrichment of $500 \mu \mathrm{g}$-at $\mathrm{NO}_{3}-\mathrm{N}^{-1}$, and $0.1 \mathrm{ml}$ phosphate solution, corresponding to an enrichment of $30 \mu \mathrm{g}$-at $\mathrm{PO}_{4}-\mathrm{P} \mathrm{I}^{-1}$, it was tested whether nutrient competition or perhaps other factors were responsible for the phenomena observed. The small and highly motile cells of $P$. micans could not be counted exactly under the dissecting microscope, thus generation time of this species was only estimated. Final cell yield at the end of the experiments was counted in the inverted microscope in the fixed samples.

\section{RESULTS}

\section{Generation time}

Generation times with confidence limits ( $95 \%$ level) of the algae tested in monoculture are presented in Table 2. Generation times with confidence limits for Biddulphia regia in monoculture and in multi-species cultures and the same for Coscinodiscus concinnus are given in Table 3 . Both species revealed no statistically significant differences in generation time neither in monocultures nor in multispecies cultures.

Table 2

Géneration time plus confidence limits (95\% level) of the diatoms Biddulpbia regia (BID), Coscinodiscus concinnus (COS) and of the dinoflagellates Ceratium horridum (CER) and Prorocentrum micans (PRO) in unialgal cultures at $18^{\circ} \mathrm{C}, 3300$ lux and a $14: 10$ light-dark cycle

\begin{tabular}{|cccc|}
\hline BID & COS & CER & PRO \\
\hline $19.7 \leqq 20.9 \leqq 22.3$ & $43.7 \leqq 50.0 \leqq 58.5$ & $49.7 \leqq 58.3 \leqq 73.4$ & $45.8 \leqq 50.5 \leqq 56.4$ \\
\hline
\end{tabular}

In Ceratium horridum cultivated together with Coscinodiscus concinnus, generation time is the same as in unialgal cultures. However if cultivated together with Biddulphia regia or with $B$, regia plus Coscinodiscus concinnus, $C$. borridum divided only 3 to 4 times. While an exact determination of the generation time is not possible, the data suggest that it is the same in the multi-species cultures as in the controls. 
Table 3

Generation time plus confidence limits (95\% level) of the diatoms Biddulphia regia (upper part) and Coscinodiscus concinnus (lower part) in unialgal and multi-species cultures. (For Culture conditions and abbreviations consult Table 2)

\begin{tabular}{cccc|}
\hline BID & BID + COS & BID + CER & BID + COS + CER \\
\hline $19.7 \leqq 20.9 \leqq 22.3$ & $20.5 \leqq 22.2 \leqq 24.3$ & $20.3 \leqq 21.9 \leqq 23.8$ & $19.9 \leqq 22.6 \leqq 26.1$ \\
\hline COS & COS + BID & COS + CER & COS + BID + CER \\
\hline $43.7 \leqq 50.0 \leqq 58.5$ & $40.7 \leqq 45.0 \leqq 50.2$ & $39.1 \leqq 43.1 \leqq 48.1$ & $45.3 \leqq 49.3 \leqq 54.1$ \\
\hline
\end{tabular}

The few data from the second set of experiments which can be used for calculating the generation time of Prorocentrum micans suggest that this species too remained unaffected, as far as its generation time is concerned by the other species present.

\section{Production}

Mean cell density during the stationary phase of Biddulpbia regia monocultures (number of cultures: $\mathrm{n}=12$ ) was 2230 cells $10 \mathrm{ml}^{-1}$, cell yield varied between 2050 to 2572 cells $10 \mathrm{ml}^{-1}$. There was no difference if cultivated together with Ceratium borridum $(\mathrm{n}=6)$. If cultivated together with Coscinodiscus concinnus $(\mathrm{n}=6)$ or with C. concinnus plus $C$. horridum $(\mathrm{n}=6)$, cell production was significantly lower, the mean ( $\mathrm{n}=12$ ) was 1693 cells $10 \mathrm{ml}^{-1}$; variations ranged from 1540 to 1850 cells $10 \mathrm{ml}^{-1}$ (Fig. 1). If nutrients were added, B. regia always started to divide again. It is concluded that nutrient competition caused growth limitation in this species.

Coscinodiscus concinnus showed no difference in cell production in the multispecies cultures as compared with monocultures. There were 12 monocultures, 6 cultures together with Biddulphia regia, 6 together with Ceratium borridum and 6 together with $B$. regia plus $C$. horridum. The cell density of these 30 cultures varied between 60 and 70 cells $10 \mathrm{ml}^{-1}$. If nutrients were added to stationary-phase cultures, C. concinnus again started cell production; it is concluded that nutrient limitation caused growth limitation (Fig. 1).

Ceratium horridum was extremely sensitive to the presence of Biddulphia regia but not to that of Coscinodiscus concinnus. In monocultures, this species produced 450 to 750 cells $10 \mathrm{ml}^{-1}$. If cultivated together with $B$. regia, $C$. horridum divided only once or not at all after $B$. regia had reached the stationary phase. $B$. regia has a generation time of about $21 \mathrm{~h}$, whereas that of $C$. horridum exceeds 2 days; the latter could, therefore, divide only 3 to 4 times before $B$. regia went into stationary phase. As a consequence, $C$. horridum produced only 30 to 50 cells $10 \mathrm{ml}^{-1}$, i.e. about $10 \%$ of the production of the controls (Fig. 1).

If nutrients were added, only Biddulphia regia renewed population growth. In order to decide whether growth limitation was caused by nutrient competition or by inhibiting factors excreted by B. regia, medium from the stationary-phase mixed cul- 
tures was decanted into a new Petri dish, enriched with nitrate plus phosphate as described, and inoculated with 4 cells of Ceratium borridum. The dinoflagellate started to divide without a lag phase, and its generation time equalled that of the controls; the total cell yield was between 300 and 400 cells. Thus it can be concluded that only nutrient limitation is responsible for the lower $C$. horridum cell numbers obtained in mixed cultures with $B$, regia.

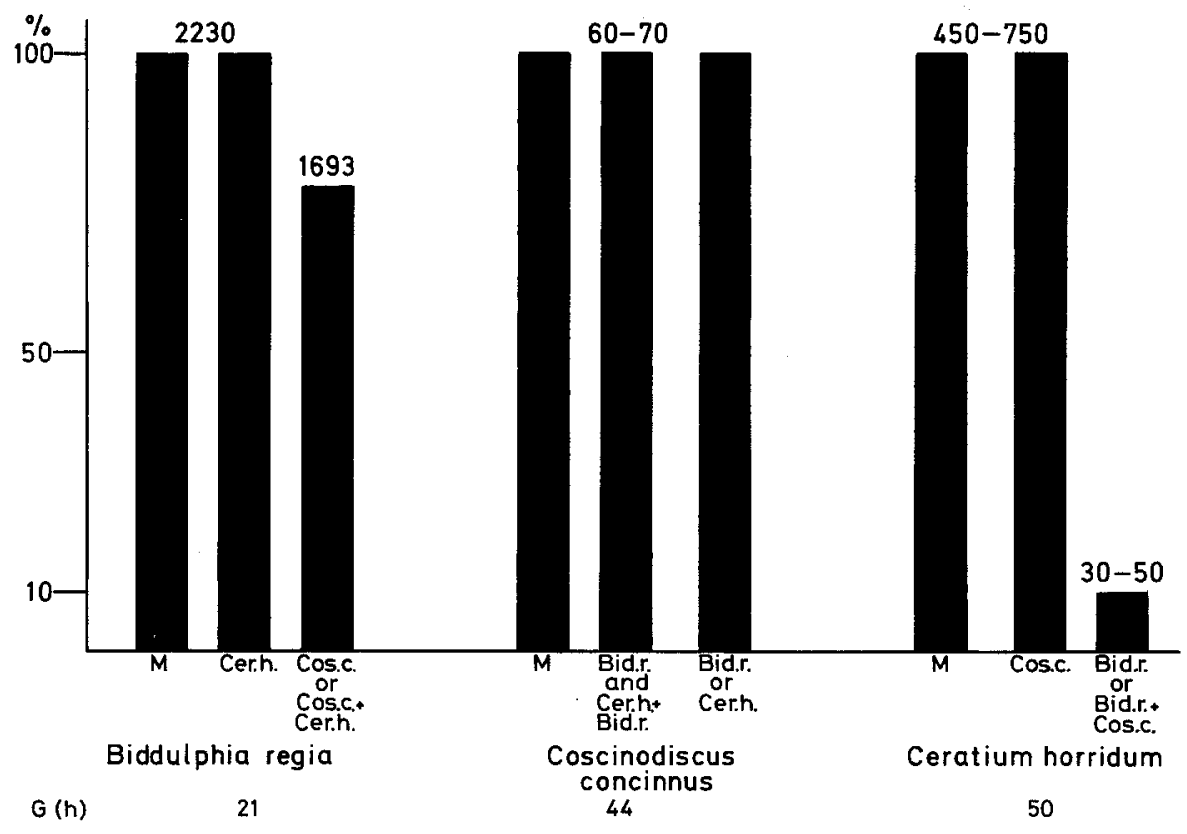

Fig. 1: Cell production gained in stationary-phase cultures of Biddulphia regia (Bid. r.), Coscinodiscus concinnus (Cos. c.) and Ceratium borridum (Cer. h.), expressed as per cent of monocultures, in multi-species cultures and in monocultures (M). Numbers above black columns: number of cells in stationary-phase cultures. $G(h)$ : generation time in hours

If cultivated together with Coscinodiscus concinnus, Ceratium borridum continued to divide even if $C$. concinnus was in the stationary phase. C. horridum apparently produced the same cell density as in monocultures, but as the cell number varied to a large extent in the monocultures ( 450 to 750 cells) only a large number of experiments can reveal possible slight differences.

Prorocentrum micans, if cultivated together with Biddulpbia regia, divided only once after $B$. regia had reached the stationary growth phase. In mixed cultures of $P$. micans and Coscinodiscus concinnus, the dinoflagellate gained each time about 1000 cells $10 \mathrm{ml}^{-1}$. There was no difference, no matter whether the inoculum consisted of 5 cells, 10 cells or as many as 50 cells. If nutrients were added both, $P$. micans and C. concinnus started to divide again.

In order to examine the possibility that inhibition due to algal excretion may have been responsible for limiting population growth, 10 Prorocentrum micans cells 
were inoculated into monocultures of either Biddulphia regia or Coscinodiscus concinnus which had entered the stationary growth phase 2 days before. The growth of $P$. micans was followed. In stationary-phase cultures of $B$. regia with no nutrient enrichment, the inoculated cells of $P$. micans divided only 1 to 2 times. After enrichment with nutrients, in $P$. micans as well as in $B$. regia cell division was resumed. If inoculated in stationary-phase monocultures of $C$. concinnus, $P$. micans attained a final cell density of about 200 to 500 cells, equivalent to at least 4 to 5 cell divisions. Hence, there is no reason to assume that an inhibitioning factor had been excreted into the medium. Consequently, growth limitation must have been caused by nutrient competition.

In conclusion, with respect to cell-production several different growth patterns exist in multi-species cultures (Fig. 1). We distinguish 3 types: (1) No effect on either of the species co-cultivated. This applies to Coscinodiscus concinnus and Ceratium borridum. (2) No effect on one of the species, but on the others. This applies to Coscinodiscus concinnus (no effect) if cultivated together with Biddulphia regia or B. regia plus Ceratium horridum or Prorocentrum micans. (3) All species of multi-species cultures failed to yield the same cell density as in monocultures. One species yielded more than half (Biddulphia regia), the other less than half the cells as compared to their monocultures (Prorocentrum micans).

Theoretically, there are a number of further, possible growth patterns not demonstrated in the present experiments; these may perhaps be found if more combinations are tested.

\section{DISCUSSION}

Competition is a factor attracting increasing interest in ecological research. In recent years, some papers dealing with the theoretical background of this phenomenon have appeared, for references and discussion see O'Brien (1974), Wiegert (1974), Vandermeer (1975) and others. Nevertheless, papers dealing with multi-species algal cultures are rare, e.g., Kroess $(1971,1972)$ and Elbrächter (1976). If two or more algae are cultivated together in a defined volume of water, it can be expected that there will be some influence on the growth of one or more members of mixed cultures. Such an influence might effect growth or cell composition.

In this study, the possible influence on growth is investigated, the parameters measured being generation time and cell production. Generation time is one of the most important factors influencing population dynamics. It deals with the time in which a population of known magnitude can multiply. If there is no growth limitation, this value corresponds to the time in which feeders can use the equivalent of the standing stock as food at a given time without disturbing steady-state conditions. This applies if we regard the water body in which a phytoplankton population is growing as "continuous culture" with no growth limitation of any kind.

If, on the other hand, we regard the water body in which a phytoplankton population grows as "batch culture", growth will be limited at least by nutrients. Feeders use whole cells; therefore, the amount of cells produced in a given water mass with a given nutrient concentration is of interest for modelling ecosystems. 
Growth limitation in multi-species cultures might be caused by excretion by one species suppressing growth of other species, e.g. Kroess (1971, 1972), Elbrächter (1976). In the present experiments, none of the results suggest that changes in growth rates were due to inhibition caused by excreted factors.

Carlucci \& Bowes (1970) demonstrated that liberation of vitamins produced by one species will enhance growth of other species in mixed cultures. In the present experiments, there was no growth enhancement and this possibility will not be discussed further.

In our experiments, generation time was identical in multi-species cultures and in unialgal cultures. The observed influence on growth was restricted to limitation in respect to cell production and this could be ascribed to nutrient competition. Addition of nutrients to stationary multi-species cultures resulted in further cell division.

There are some possible mechanisms of nutrient competition which cause growth limitation. According to Dugdale (1967), Eppley et al. (1969) and others, nutrient uptake can be described by an equation similar to that of Michaelis-Menton enzyme kinetics. It was demonstrated by various authors that different species can have different uptake rates and half-saturation constants for different nutrients. These authors concluded that cell division and generation time will depend on the external concentration of the limiting nutrients. Fedorov \& Kustenko (1972) demonstrated that Skeletonema costatum and Thalassionema nitzschioides have different affinities to nitrate and phosphate. Changes in the ratio of these nutrients in mixed cultures caused subsequent changes in the biomass of the species concerned.

Droop $(1974,1975)$ concluded from his experiments with Monocbrysis lutberi that the internal nutrient status of the cells regulate cell division. In addition, he demonstrated that algal cells have the possibility of luxury consumption. However, Droop also demonstrated that luxury consumption of a non-limiting nutrient is regulated by the concentration of a limiting nutrient. If growth stopped by nutrient limitation of one nutrient, luxury consumption of another nutrient, present in excess, stopped also. This mechanism can significantly effect growth limitation in mixed algal cultures.

Perhaps, one of the phenomena observed during the present experiments may be explained by this last-mentioned mechanism: the growth limitation of Ceratium borridum cultivated together with Biddulpbia regia. The dinoflagellate showed no growth in mixed cultures after nutrient enrichment of stationary phase cultures. In contrast, $B$. regia cells began to divide after nutrient enrichment. If inoculated into enriched medium decanted from stationary-phase $B$. regia cultures, $C$. horridum showed good growth. Thus, inhibition by excreted factors can be excluded. The explanation for this phenomenon might be that $B$. regia has a very high uptake rate and a very high luxury consumption of the nutrients added, so that $C$. horridum had no opportunity to build up an internal substrate concentration high enough to allow cell division. As a reminder B. regia has a generation time of about $21 \mathrm{~h}$; C. horridum, of more than 2 days.

Extremely different affinities to nutrients, described by Fedorov \& Kustenko (1972), may explain why Coscinodiscus concinnus and Ceratium borridum gained the same cell yield in mixed cultures as in monocultures. No nutrient competition could 
be detected in a limited volume of medium with a limited nutrient concentration. When nitrate and phosphate were added to stationary-phase cultures, both algae started once more to grow; hence, it can be concluded that growth of both algae had been nutrient limited.

Although Coscinodiscus concinnus exhibit optimal growth below $18^{\circ} \mathrm{C}$ (personal communication of Dr. Schöne), cell yields for $C$. concinnus obtained under optimal conditions (Schöne, unpublished) did not differ significantly from the results found at $18^{\circ} \mathrm{C}$. Therefore, it is unlikely that the results of the multi-species cultures discussed here were influenced by temperature conditions sub-optimal for $C$. concinnus.

Growth limitation due to nutrient competition between Biddulphia regia and Prorocentrum micans may be explained by equal demands and equal uptake rates for nutrients in both species. In mixed cultures, these two species stopped cell division at the same time and, if nutrients were added, both started to grow again.

Our experiments demonstrated a variety of possible interactions and reactions regarding production of phytoplankton species if cultivated in mixed cultures. Further investigations in the field as well as in the laboratory are required to show whether these or other mechanisms apply to interactions of coexisting phytoplankton species in natural habitats.

Acknowledgements. The author gratefully acknowledges financial assistance from the Deutsche Forschungsgemeinschaft. Sincere thanks are due to Prof. Dr. L. Aletsee, Botanisches Institut, Aachen, who offered criticism and suggestions. I also like to express gratitude to Dr. H. K. Schöne, Botanisches Institut, Aachen, who supplied unpublished data and critically read the manuscript. Dr. H. J. Krambeck made the statistical analyses. Mrs. A. Schöne provided technical assistance and Mrs. H. Harbst made the drawing.

\section{LITERATURE CITED}

Carlucci, A. F. \& Bowes, P. N., 1970. Vitamin production and utilization by phytoplankton in mixed culture. J. Phycol. 6, 393-400.

Droop, M. R., 1974. The nutrient status of algal cells in continuous culture. J. mar. biol. Ass. U.K. 54, 825-855.

- 1975. The nutrient status of algal cells in batch culture. J. mar. biol. Ass. U.K. 55, 541-555.

Dugdale, R. C., 1967. Nutrient limitation in the sea: dynamics, identification, and significance. Limnol. Oceanogr. 12, 685-695.

Elbrächter, M., 1976. Population dynamic studies on phytoplankton cultures. Mar. Biol. 35, 201-209.

Eppley, R. W., Rogers, J. N. \& McCarthy, J. J., 1969. Half saturation constants for uptake of nitrate and ammonium by marine phytoplankton. Limnol. Oceanogr. 14, 912-929.

Fedorov, V. D. \& Kustenko, N. G., 1972. Competition between marine planktonic diatoms in monoculture and mixed culture. Oceanology 12, 91-100.

Kroess, H. W., 1971. Growth interactions between Chlamydomonas globosa Snow and Chlorococcum ellipsoideum Deason and Bold under different experimental conditions, with special attention to the role of $\mathrm{pH}$. Limnol. Oceanogr. 16, 869-879.

- 1972. Growth interactions between Chlamydomonas globosa Snow and Chlorococcum ellipsoideum Deason and Bold: the role of extracellular products. Limnol. Oceanogr. 17, 423-432.

O'Brien, W. J., 1974. The dynamics of nutrient limitation of phytoplankton algae: a model reconsidered. Ecology 55, 135-141. 
Stosch, H. A. von \& Drebes, G., 1964. Entwicklungsgeschichtliche Untersuchungen an zentrischen Diatommen IV. Helgoländer wiss. Meeresunters. 11, 209-257.

Vandermeer, J. H., 1975. Interspecific competition: A new approach to a classical theory. Science, N.Y. 188, 253-255.

Wiegert, R. G., 1974. Competition: a theory based on realistic, general equations of population growth. Science, N.Y. 185, 539-542.

Authors adress: Dr. M. Elbrächter

Biologische Anstalt Helgoland (Litoralstation)

Hafenstraße 3

D-2282 List/Sylt

Federal Republic of Germany 